\title{
Heritage cuisine and identity: free time and its relation to the social reproduction of local food
}

\section{Humberto Thomé-Ortiz}

To cite this article: Humberto Thomé-Ortiz (2017): Heritage cuisine and identity: free time and its relation to the social reproduction of local food, Journal of Heritage Tourism, DOI: 10.1080/1743873X.2017.1343336

To link to this article: http://dx.doi.org/10.1080/1743873X.2017.1343336

曲 Published online: 27 Jul 2017.

Submit your article to this journal

Q View related articles $\longleftarrow$

View Crossmark data \lceil 


\title{
Heritage cuisine and identity: free time and its relation to the social reproduction of local food
}

\author{
Humberto Thomé-Ortiz \\ Instituto de Ciencias Agropecuarias y Rurales, Universidad Autónoma del Estado de México, Toluca, Mexico
}

\begin{abstract}
Mexico City is the world's fourth largest metropolis with more than 20 million inhabitants. Due to its integration with a global world, the dietary habits of its population have undergone significant transformations, which include an increased consumption of industrialized products. At the same time, there is a growing interest in local food consumption, linked to aspects such as health, the environment and cultural identity. One of the most consumed traditional foods in central Mexico is slow-cooked lamb (barbacoa de borrego), a dish prepared with the Mayan 'pib' cooking method, which consists of using an earthen oven in which the animal is placed, wrapped in maguey cactus leaves and cooked throughout an entire night. Texcoco is a small city 40 kilometres outside of Mexico City whose fame for preparing barbacoa attracts thousands of visitors every weekend. The purpose of this work is to analyse the role that personal identity and free time play in the reproduction of heritage cuisine in contemporary societies. It concludes that tourism practices enable the continuity of certain local foods, reinterpreted in the light of urban consumption.
\end{abstract}

\section{ARTICLE HISTORY}

Received 26 September 2015 Accepted 11 June 2017

\section{KEYWORDS}

Heritage cuisine; local food; identity; free time; socialization; central Mexico

\section{Introduction}

In recent decades, tourism studies have turned their interest towards the link between cultural heritage and tourism (Timothy \& Boyd, 2006). Given the importance that cultural heritage has in society's economic development, some work has centred on its interpretation, planning and management as a tourism resource (Nuryanti, 1996). Currently, food heritage constitutes one of the main tourist attractions of any destination, given that food is a marker of regional identity and a focal point in the tourist experience. As a result of this, a central theme in gastronomic tourism studies is the analysis of the impact that tourism practices have on the patterns of continuity and transformation of local food (Timothy, 2016a; Timothy \& Ron, 2013).

During the last decade, various studies have been done on the link between food and tourism, which have branched into three areas of focus. The first analyses the role of cuisine heritage as a tourism resource for the economic development of producer regions (Ab Karim \& Chi, 2010; Boyne \& Hall, 2004; Du Rand, Heath, \& Alberts, 2003; Frochot, 2003; Kim, Yuan, Goh, \& Antun, 2009; Lin, Pearson, \& Cai, 2011; Okumus, Okumus, \& McKercher, 2007; Ottenbacher \& Harrington, 2013; Stanley \& Stanley, 2015). The second studies the behaviour, motivations and expectations of tourists with regard to local food (Eric Amuquandoh \& Asafo-Adjei, 2013; Frisvoll, Forbord, \& Blekesaune, 2016 ; Kim \& Eves, 2012; Kivela \& Crotts, 2006; Mak, Lumbers, Eves, \& Chang, 2012; Quan \& Wang, 2004; Son \& Xu, 2013). The third evaluates the sociocultural impacts of tourism and its influence in transforming local food (Avieli, 2013; Everett, 2012; Gyimothy \& Mykletun, 2009; Ron \& Timothy, 2013; Teixeira \& Ribeiro, 2013; Thomé-Ortiz, 2015, 2008). 
A good portion of these studies focuses on the valuation of food as a tourism resource, while another body of work develops a critique of the influence of tourism on the transformation of local cooking. However, few works exist that analyse the role of tourism in the social reproduction of food-based heritage (Timothy, 2016a).

Presenza and Del Chiappa (2013) study the attitude of restaurants toward incorporating local food as a stamp of regional identity in their gastronomic offering. Hall (2013) analyses the continuity of recreational foraging for wild edibles, in which the influences of traditional cultures, identity and nostalgia are observed. Despite this, no studies were found that specifically analyse the role that personal identity and free time play in the preservation of cuisine heritage in contemporary society.

As a contribution to the body of knowledge about this phenomenon, this work analyses the role played by the personal identity of Mexico City inhabitants and the dynamics of their free time in the preservation of an emblematic dish from the Mexican Plateau region's cuisine. Given the complexity and the high cost of preparing this traditional slow-cooked lamb, the dish has become unfeasible in the everyday diet of urban residents, but it is presumed that its consumption as a tourist attraction enables the social reproduction of this local food item. The results indicate that the cultural popularity of traditional cooking, the availability of free time and economic capital are the three significant elements for the reproduction of heritage cuisine in a global world.

This work begins with a reflection on the transformation of food in Mexico City, which is characterized by an increase in the consumption of processed food and its resulting forms of resistance through the consumption of traditional food. Later, the relationship between free time and heritage cuisine is addressed through the valuation of local food as a tourism resource capable of creating differentiated experiences. The way in which free time and identity influence the reproduction of heritage cuisine is addressed from the perspective of the family dynamics of food consumption. Then, the methodological design is presented along with the study area and the categories of analysis employed in the investigation. Next, the results of the investigation are given from the perspective of visitors. Finally, the work's principal conclusions are presented, as well as its theoretical contribution and perspectives on future research.

\section{In between local and global: the transformation of food in Mexico City}

Mexico City has experienced significant cultural changes related to its strong integration with global markets (Ward, 1998). Considerable transformations have occurred in the eating patterns of its inhabitants, consisting of the increased consumption of industrial food (García \& Bermúdez, 2014). At the same time, some segments of the population are showing interest in consuming local foods with high sociocultural significance, which displays the important relationship between humans and eating in the phenomenon of food (Kooijmans \& Flores-Palacios, 2014).

In turn, food consumption in urban areas plays an important role as an element of social differentiation, associated with consumers' display of economic and cultural capital (Bourdieu, 1987). In countries like Mexico, where local and global products overlap, a cultural hybridization is created that allows for entering and exiting modernity (García-Canclini, 1995) by means of consumption in which industrial and traditional foods coexist in groups of fairly heterogeneous consumers.

In the case of traditional food that requires laborious preparation, greater availability of economic resources and time are essential for its consumption, since these elements correspond to a use of time that differs from an urban lifestyle. The consumption of this type of food, due to its differentiated attributes, translates into nutritional and cultural 'benefits' for those who consume them. This illustrates the way in which cultural patrimony is converted into a key element in the development and quality of life of contemporary society (Di Pietro, Mugion, \& Renzi, 2014).

\section{Heritage cuisine as a tourism resource}

In contemporary society, heritage cuisine is valued in very different ways, including by means of the material and symbolic dimension of food. One way that heritage cuisine is valued, within the service- 
based society (Lipovetsky \& Serroy, 2015), is through tourism. This is possible since some types of food create demand for travel to the regions in which they are produced, by means of a differentiated tourism opposing that of the mass-market models of tourism (Warden \& Tomlinson, 1995).

Selecting certain food items as patrimonial objects is a way in which society discretionally assigns a value to products. And so some food items acquire an elevated status beyond their conventional meanings as a food item, which, through the act of 'eating out', involves entertainment and cultural consumption (Warden \& Martens, 2000).

One of the principal means of identification between society and food comes from the conception of the latter as a marker of regional identity. In this way, the association between space and heritage cuisine opens the possibility to utilize local food as a key element for local development, since it is the food tied to the region that has the greatest likelihood of attracting tourists' interest.

Different works have drawn attention to the importance of traditional foods as a tourism resource for economic development (Avieli, 2013; Bessiere, 1998; Bessière, 2013; Cohen \& Avieli, 2004; Omar, Karim, Bakar, \& Omar, 2015). However, few studies exist that address the role of tourism in the social reproduction of cuisine heritage. In other words, beyond tourism's function as an economic activity, there has been little study of its impact, such as political and social action that promotes the preservation of heritage and maintaining people's quality of life.

In the case of Mexico, the majority of traditional food is produced in rural spaces, which is associated with an idyllic representation of the past, where it is possible to compensate for lost identity by means of journeys as a tourist (Bessiere, 1998). In this way, the urban demand for local food is constructed from an ideological perspective that has deep ties with the materiality of an envisioned ruralism (Bell, 2006).

The urban consumption of traditional food brings different types of mobilities into play, many of them only possible during free time. Therefore, tourism's appropriation of local products is subordinated to aspects such as resource availability, the proximity of urban centres and the product's reputation. Thus, culinary tourism may be thought of as a phenomenon associated with increasingly fragmented free time and with the growth of the middle class, aspects that impact the increase in short trips to nearby destinations (Hiernaux, 2005). Gastronomic trips are a practice of food consumption by means of which tourists travel to rural outskirts in search of the authenticity present in local food. This contrasts with daily life in large cities, characterized by a non-local and impersonal diet.

\section{Free time, family and food: the social reproduction of local products}

The use of free time has a close relationship with family food dynamics. In the case of urban societies, dietary practices are increasingly related to consumption and services, with tourist trips being a way in which big city residents can access traditional food. Social reproduction of heritage cuisine and its relationship with generational changes, in the context of globalization, are themes that had already been studied in Europe for more than two decades (Fantasia, 1995). However, despite the strong market presence of fast food chains and the high vulnerability of cuisine heritage, they are littlestudied phenomena in Mexico.

The transmission of heritage cuisine implies an intergenerational legacy, whose transmission happens within the core of family eating practices (Timothy, 2016b). Based on these, references are built that influence the construction of food identities of the younger generations.

Heritage cuisine does not only feed the human body, but also the social body (Muchnik, 2006). In other words, dishes with history and with a high sociocultural content fulfil an important structural function within society and therefore these food items are still available on markets, despite their apparent incompatibility with modern lifestyles. On the other hand, it is important to consider that because the demands of the urban lifestyle, the dietary practices of contemporary societies are increasingly individualistic, and the social nature of dietary practices is quickly fading. This converts free time into the preferred setting for social get-togethers around a meal, and through all that comes with the act of eating alongside other people. 


\section{The case of Texcoco barbacoa}

Texcoco is a small city 40 kilometres from Mexico City, whose reputation for the preparation of slow-cooked lamb, barbacoa de borrego, is based on a product that is highly valued by urban consumers and a large source of income for its producers. The connection between the name Texcoco and high-quality barbacoa is a good example of what was described by Moon (2008) in South Korea, regarding the local dishes as powerful regional markers.

Lamb barbacoa is a traditional dish widely consumed in Mexico's central region. It is prepared using the Mayan slow cooking method called 'pib', in which an animal wrapped in maguey cactus leaves is placed whole into an earthen oven for an entire night (Thoms, 2009). Because of its complex preparation, it is a food that is usually eaten at parties and on holidays (Adapon, 2008; Rubio, Torres, Gutiérrez, \& Méndez, 2004). Preparing this dish requires three hours to heat the earthen oven and another six hours to cook the meat and extract a stock called consomé. Its preparation, more than a ritual, constitutes a culinary technique where the quality is associated with physical labour, skilful elaboration and masterly knowledge of the product. This product provides a way of life for its producers and a representation of local culinary excellence (Adapon, 2008).

Barbacoa consumption is found in traditional markets at the weekend, where the product is purchased by weight for between 20 and 40 US dollars a kilo. It is a hearty meal that invites social consumption in which taste and economic status are underlying factors. Although inhabitants in central Mexico are frequent consumers of barbacoa, their opinion on the product's quality and the eating dynamics are under-explored subjects.

\section{Methods}

During 2013 and 2014, a qualitative case study (Stake, 2000) was carried out with the goal of understanding the way in which free time and food identity influence the reproduction of heritage cuisine. To achieve this, the study analysed the social significance in relation to the use of free time for consuming an emblematic food. This work focused on the following research question: Is the availability of free time and economic resources, combined with a food identity based on family dynamic, the fundamental element in preserving heritage cuisine in the context of a late-capitalist service society?

To answer this question, the study was divided into five phases. In the first phase, a research document was created on the relationship between food and tourism that contains works beginning with the early twenty-first century. The second phase consisted of the case selection by means of theoretical sampling, in which a specific phenomenon was sought that illustrates the relationship between free time, identity and the reproduction of heritage cuisine. In the third phase, the research instruments were designed including the guidelines for in-depth interviews and participant observation. The fourth phase consisted of the intensive field work to collect qualitative data. During the fifth phase, the data analysis was performed, using a systematic process of categories of analysis that were compared with other cases (Eisenhardt, 1989; Eisenhardt \& Graebner, 2007).

The selection of subjects was performed by means of a non-probabilistic snowball sampling method (Goodman, 1961), from which it was determined to conduct 100 semi-structured interviews with visitors who had the following characteristics: they are a Mexico City resident; they are motivated to visit Texcoco to eat barbacoa; and they are part of a group travelling as a family. ${ }^{1}$ The interview questions were answered by one member of each family in the study. The total sample was sought to be equal in terms of age and gender. This number of interviews allowed for a saturation of results; in other words, after reaching that interview quantity, the incremental gain of knowledge was minimal.

The interviews were held in 25 establishments, which represented $100 \%$ of the businesses where barbacoa is sold and consumed inside the Texcoco municipal food market. In addition to its centuryold tradition for the sale of barbacoa, this market was selected as a unit of observation according to 
the following criteria: it has an emblematic food product; it has visitor demand for said product; and it is located in a suburban zone no farther than 50 kilometres from Mexico City.

The interviews centred on aspects related to the characteristics of barbacoa consumers, the appreciation of the quality of the regional product, and the link between free time and food consumption. The interview script consisted of 32 questions organized into three sections. The first section addressed the aspects relative to the profile of the consumer, with the goal of understanding the social, economic and cultural makeup of barbacoa consumers. The second part addressed questions related to consumption dynamics, which investigated aspects such as frequency of consumption, the quantity consumed, days of consumption, and the social forms and patterns of consumption. The third part investigated the social construction of barbacoa quality from the consumer perspective. The data were complemented with information taken from participant observation, whose guidelines were the family dynamics of the diners, the manner in which people spent their time in the barbacoa stands and the way in which the product is served and eaten.

\section{The barbacoa experience}

\section{Urban consumers of local products}

The consumption of local food such as barbacoa is strongly associated with enjoying free time at the weekend. Barbacoa consumption implies a social act centred on the family, given that it involves hearty food that is usually sold by the kilo and invites one to gather around a table to share it. The families felt that the act of uniting to eat barbacoa on weekends strengthens the ties between their members. This act involves groups between three and five members that, according to information given by barbacoa vendors, are increasingly smaller groups. The interview subjects agree with this aspect:

When we were kids my father would bring us from Coyoacán. We never fit in the car, we travelled like sardines but it was a nice trip to go all the way to Texcoco. Now with the motorway we get there quickly and we only have two children. We get here more comfortably but it's not the same as those times.

The decrease in the number of members of urban families has an impact on the reduction of barbacoa consumption per family unit, but given total population growth the absolute consumption has maintained its level and has even increased, according to information given by the vendors. The memories of Sunday excursions by large families gives a glimpse of the longing for a past that is recovered by means of a practice, one that is as relatively simple as leaving the city to eat barbacoa.

The development of communication channels is an aspect that benefits the mobility of people and products via tourism. This occurs in such a way that nowadays heritage food has emerged as an element of nomadic material culture, in which regional interconnection enables the experience of a longed-for past through the use of free time.

The heads of family interviewed usually had a level of education between high school and university. They are employees and independent white-collar workers, middle class, who have free time at the weekend when they use their disposable income for recreation and to eat as a family. In the case of barbacoa, due to its high cost, it involves a special dish that is consumed predominantly at the weekend and on holidays. Aside from its labour-intensive preparation, the aforementioned has to do with the time needed to eat the product as a family, to get together and talk around a table and to stay at the table once the meal is finished, to allow time to digest the copious food.

All the interviewed subjects clearly expressed that the principal motive for their trip to the city of Texcoco is to eat a 'high quality, traditional barbacoa'. The consumption of local products is a clear trend in the use of free time, as demonstrated in other studies, such as in Henderson (2009).

Every time it's payday my husband treats us to barbacoa here in Texcoco. It's a special day when we do something different. We have fun.

The consumption of barbacoa on weekends is a strongly rooted tradition for the interviewed families. One very common aspect between the interview subjects is their ability to refer to up to 
three generations of continuity within the same family (grandparents, parents and children) that eat and have eaten barbacoa from the same family of barbacoa producers with the passage of time. This continuity reveals a relationship between food habits, family identity and the availability of free time as three categories that allow the reproduction of heritage cuisine by the younger generations. The barbacoa sellers, for their part, relate that the sustainability of their businesses is strongly associated with the urban consumers' practices in their free time.

The relationships between barbacoa producers and consumers are based on interpersonal connections with hints of affection. In this interaction, loyalty is linked to relationships of trust, built through several generations. The same families of consumers continue to buy from the same families of producers where, despite sociocultural changes, the system of traditional production has stayed the same throughout the passage of time

We always come here to eat barbacoa. My father brought us as kids and his father brought him as a child.

Since I can remember, on Sundays the market comes to life. The people who visit us from Mexico City are those who have always come to buy barbacoa from us on their days off.

The widespread interest among the interview subjects to eat 'traditional food', such as Texcoco barbacoa, coincides with MacCannell (1976), with respect to the necessity of breaking with homogeneous consumption of industrialized food in metropolises.

\section{The consumption of local products and consumer capacity}

Consuming barbacoa requires the display of economic, social and cultural capital, the possession of which allows a person to identify and share a quality meal. This is an aspect that agrees with the Bourdieu's (1987) description of consumption as a mechanism of social differentiation. The aforementioned signifies that the consumption of quality local products is associated with personal identity and an inherited awareness, aspects that were previously described by Bessière (2013) in rural regions in France.

The capacity to appreciate and locate a well-prepared barbacoa is a skill transmitted from parents to children, a fact that implies the awareness of 'far-away' places and establishments with good food; in other words, the ability to enjoy quality free time as a family. My mother always taught us to eat good things and she was a frequent client of this business. Here the barbacoa
isn't dry or greasy and Mr Pedro's cooking skills are the same as always.

\section{The social construction of the quality of local products}

The determination of the quality of barbacoa can be understood as a subjective construct, but it is socially conditioned by family practices. These practices are associated with psychological, social and cultural aspects that decide the dynamics of consumption and consumer preferences.

I like barbacoa from this stand because it is fresh and the meat is tender, it's full of flavour. I've always liked that Mr Trujano is very clean and makes us feel at home. Coming here means having a good time.

The barbacoa consumers appreciated four aspects in particular:

- The product's good flavour, associated with the producer's culinary skill, which they base their preference for a certain establishment;

- The freshness of the product, specifically the importance of having recently taken the meat out of the oven, with remarkable tenderness and served at high temperature, since the lamb fat is usually very heavy. Freshness is not common in restaurants in the city, where they resell artisanal barbacoa from the markets, and reheat it when they receive an order. In Texcoco the product is closer to market, which is why it is always available fresh; 
- The meat, wrapped in roasted maguey cactus leaves and prepared in an earthen oven, is a feature that attracts visitors to places where barbacoa is still made with traditional methods.

- The service quality of the vendors, which translates into their friendliness towards customers and the cleanliness of the stand.

We come all the way to Texcoco for barbacoa because it tastes different. Here they make it the traditional way in an earthen oven and they serve handmade tortillas. This is real food, like from before, that you can't get any more in the city.

Other variants of barbacoa exist which are prepared in metal pots to simplify the process, but their flavour differs greatly from barbacoa made in earthen ovens. New products are also seen such as barbacoa made from rabbit, chicken, pork and beef, which agrees with the concept of 'invented heritage cuisine' described by Avieli (2013) in central Vietnam.

The perceived quality of the barbacoa in Texcoco, with respect to other barbacoas in central Mexico, is derived from its social construction as an iconic food product (Freidberg, 2003) whose identification is a skill that has been cultivated historically within social groups. In another sense, it is possible to think of the product's future transformation, caused by the pressure of demand from tourism, which agrees with another study by Cohen and Avieli (2004) on the changes in traditional products related to tourism. The younger generations showed a preference for lean meats, with less offal, smaller corn tortillas and dipping sauces that are less spicy. Everything related to health and aesthetic concerns was perceived by the younger consumers.

\section{Consuming local food in the context of the globalization of cuisine}

One of the reasons urban visitors travel to Texcoco in search of traditional barbacoa is the desire to consume a carefully elaborated product in a relaxed setting. Both of these aspects were reported by the interview subjects as motives for the visit. As well, from the perspective of the interviewed consumers, consuming lamb barbacoa can be interpreted as a quality of life indicator, given that it implies the availability of free time for families to relax together, availability of fresh, healthy and carefully prepared food, and availability of economic capital to obtain quality food.

When I have a bit of money I like to bring the family to eat barbacoa, since in the end, what we eat and what we do is what we take to the grave, and the good memories are what we leave to those who stay.

The consumption of barbacoa certainly reflects a practice with deep hedonistic significance, which has been reproduced by generations of families in central Mexico. The act of eating is a typical way for urban segments to take advantage of free time at the weekend. It is a time when they seek food that cannot be found within the gamut of the industrialized products of large metropolises, and in this context, local products have a comparative advantage.

The meanings given to barbacoa consumption among the members of the same family are often a very diverse nature. According to Cohen (1979), the authenticity of food is a subjective construct that has difference meanings for different types of tourists. For the majority of men, it is a practice of liberation from the psychosocial tensions created by their job, while for the women it represents a retreat from their domestic labours related to the social responsibility of making food for others (De Vault, 1991).

For me, coming to Texcoco means waking up later than usual, putting on comfortable clothes, driving relaxed without any traffic, to eat a good barbacoa taco. For my wife, it's a day when she doesn't wash dishes, she doesn't serve the food and it's her turn to be waited on. For the kids it's like a holiday that they spend playing and laughing.

In the specific case of Texcoco, it was observed that in addition to consuming traditional barbacoa, an increasing number of visitors expressed particular interest in enjoying the natural and cultural resources of the rural outskirts of Mexico City. The resources that most interest the interview subjects 
include archaeological sites, traditional handmade objects, historic monuments, the natural landscape and the provincial atmosphere. This denotes that the connection between food and tourism is related to the wide variety of natural and cultural services that rural spaces offer to urban societies.

\section{Conclusions}

This work makes it possible to understand the role that heritage cuisine plays in the formation of the cultural identity of urban societies, through a complex process that goes from the individual to the collective. This identity is transferred, incorporated and reaffirmed by means of different practices that are increasingly oriented more towards cultural consumption than everyday eating practices. The aforementioned supposes the confinement of heritage cuisine to the service sphere, as local products are positioned as regional specialties far removed from daily food practices in large metropolises.

According to Bessiere (1998), food identity has four dimensions: a spatial dimension that indicates the food's connection to its regional origin; a social dimension that refers to the social interactions displayed within the phenomenon of food; a symbolic dimension reflected by the value displayed toward the food; and the structural dimension that refers to the role of food as an organizing element of society via the processes of cohesion and differentiation. The consumption of food like barbacoa inserts diners into a culinary system, at the same time making them part of a social group that practices this system. Consumers' interest in Texcoco barbacoa reflects a process of social introspection in which tourism provides the opportunity to construct and strengthen the deep ties between consumers, producers, products and regions.

The transformation of urban food and its distancing from traditional cooking confines products like barbacoa to the sphere of cultural consumption via activities such as tourism. This occurs insofar as urban consumers understand the product as a regional specialty from Texcoco. The consumption of barbacoa implies the availability of free time and economic resources, a well of knowledge to identify a high-quality product, and a comfortable relationship with the producers. This implies that the development of a food identity for this dish has an important social dimension in which economic, social and cultural capital are displayed.

The quality of the product is identified by a series of material and symbolic attributes that include the product's physical characteristics, the techniques used in its preparation, and the personalized attention given to its consumers. It is true that the exchange of money, deriving from barbacoa's commercial dimension, allows for its material reproduction. This can be considered a consequence of the structural role that heritage cuisine itself plays in maintaining the quality of life of contemporary society, which is the subsequent reason for its continuity within the tastes' of customers.

Although this study centred solely on the Mexico City consumers of barbacoa, the results can be utilized to promote ancestral culinary techniques and the importance of the connection between the producers and their clients. The contribution of this work consists in being the first work to link food identity and free time with the social reproduction of heritage cuisine in central Mexico. Future research is needed to perform quantitative studies on the economic and sociocultural impacts created by tourism on the barbacoa of Texcoco.

\section{Note}

1. These characteristics were determined by a profile of barbacoa consumers in the Texcoco market based on interviews of 300 people during the month of January in 2013. These three characteristics constitute the most distinct features of barbacoa consumers.

\section{Disclosure statement}

No potential conflict of interest was reported by the author. 


\section{Funding}

This work was funded by the Consejo Nacional de Ciencia y Tecnología of Mexico (CONACYT) through the SEP Basic Science Joint Fund 2014 [242500]; and by the Ministry of Public Education through the 2013 Faculty Improvement Program.

\section{Note on contributor}

Humberto Thomé-Ortiz is Doctor in Agrarian Sciences from the Autonomous University of Chapingo; Full-time faculty at the Institute for Agricultural and Rural Sciences (ICAR) of the Autonomous University of the State of Mexico; Member of the National System of Researchers. His research areas are Local Agro-food Systems, Territorial Development, and Agro-food Tourism. He is principal investigator of the Project "Assessment of the recreational dimension of wild edible mushrooms, their socio-economic interest and their rural development prospects" funded by the Mexican National Council for Science and Technology. His most recent publication is "Traditional Mexican Cuisine and Tourism: New Meanings of Heritage Cuisine and its Sociocultural Implications".

\section{ORCID}

Humberto Thomé-Ortiz (D) http://orcid.org/0000-0002-6714-3490

\section{References}

Ab Karim, S., \& Chi, C. (2010). Culinary tourism as a destination attraction: An empirical examination of destinations' food image. Journal of Hospitality Marketing and Management, 19, 531-555. doi:10.1080/19368623.2010.49306 Adapon, J. (2008). Culinary art and anthropology. London: Berg.

Avieli, N. (2013). What is local food? Dynamic culinary heritage in the world heritage site of Hoi An, Vietnam. Journal of Heritage Tourism, 8, 120-132. doi:10.1080/1743873X.2013.767812

Bell, D. (2006). Variations on the rural idyll. In P. Cloke, T. Marsden, \& P. Mooney (Eds.), The handbook of rural studies (pp. 149-161). London: Sage.

Bessiere, J. (1998). Local development and heritage: Traditional food and cuisine as tourist attractions in rural areas. Sociologia Ruralis, 38, 21-34. doi:10.1111/1467-9523.00061

Bessière, J. (2013). Heritagisation, a challenge for tourism promotion and regional development: An example of food heritage. Journal of Heritage Tourism, 8, 275-291. doi:10.1080/1743873X.2013.770861

Bourdieu, P. (1987). Distinction: A social critique of the judgment of taste. Cambridge, MA: Harvard University Press.

Boyne, S., \& Hall, D. (2004). Place promotion through food and tourism: Rural branding and the role of websites. Place Branding, 1, 80-92. doi:10.1057/palgrave.pb.5990007

Cohen, E. (1979). A phenomenology of tourist experiences. Sociology, 13, 179-201. doi:10.1177/003803857901300203

Cohen, E., \& Avieli, N. (2004). Food in tourism: Attraction and impediment. Annals of Tourism Research, 31, 755-778. doi:10.1016/j.annals.2004.02.003

De Vault, M. (1991). Feeding the family: Social organization of caring as a gendered work. Chicago: The University of Chicago Press.

Di Pietro, L., Mugion, R. G., \& Renzi, M. F. (2014). Cultural technology district: A model for local and regional development. Current Issues in Tourism, 17, 640-656. doi:10.1080/13683500.2013.789006

Du Rand, G., Heath, E., \& Alberts, N. (2003). The role of local and regional food in destination marketing. A South African situation analysis. Journal of Travel and Tourism Marketing, 14, 97-112. doi: 10.1300/J073v14n03_06

Eisenhardt, K. (1989). Building theories from case study research. The Academy of Management Review, 14, 532-550. Retrieved from http://www.jstor.org/stable/258557

Eisenhardt, K., \& Graebner, M. (2007). Theory building from cases: Opportunities and challenges. Academy of Management Journal, 50, 25-32. doi:10.5465/AMJ.2007.24160888

Eric Amuquandoh, F., \& Asafo-Adjei, R. (2013). Traditional food preferences of tourists in Ghana. British Food Journal, 115, 987-1002. doi:10.1108/BFJ-11-2010-0197

Everett, S. (2012). Production places or consumption places? The place-making agency of food tourism in Ireland and Scotland. Tourism Geographies, 14, 535-554. doi:10.1080/14616688.2012.647321

Fantasia, R. (1995). Fast food in France. Theory and Society, 24, 201-243. Retrieved from http://www.jstor.org/stable/ 658098

Freidberg, S. (2003). Editorial: Not all sweetness and light: New cultural geographies of food. Social and Cultural Geography, 4, 3-6. doi:10.1080/1464936032000049270

Frisvoll, S., Forbord, M., \& Blekesaune, A. (2016). An empirical investigation of tourists' consumption of local food in rural tourism. Scandinavian Journal of Hospitality and Tourism, 16, 76-93. doi:10.1080/15022250.2015.1066918 
Frochot, I. (2003). An analysis of regional positioning and its associated food images in French tourism regional brochures. Journal of Travel and Tourism Marketing, 14, 77-96. doi:10.1300/J073v14n03_05

García, M., \& Bermúdez G. (2014). Alimentos sustentables a la carta. De la tierra a la mesa [Sustainable food a la carte. From the land to the table]. México: CALMIL - CONABIO.

García-Canclini, N. (1995). Hybrid cultures: Strategies for entering and leaving modernity. Minneapolis: University of Minnesota Press.

Goodman, L. (1961). Snowball sampling. The Annals of Mathematical Statistics, 32, 148-170. Retrieved from https:// projecteuclid.org/download/pdf_1/euclid.aoms/1177705148

Gyimothy, S., \& Mykletun, R. (2009). Scary food: Commodifying culinary heritage as meal adventures in tourism. Journal of Vacation Marketing, 15, 259-273. doi:10.1177/1356766709104271

Hall, C. M. (2013). Why forage when you don't have to? Personal and cultural meaning in recreational foraging: A New Zealand study. Journal of Heritage Tourism, 8, 224-233. doi:10.1080/1743873X.2013.767809

Henderson, J. (2009). Food tourism reviewed. British Food Journal, 111, 317-326. doi:10.1108/00070700910951470

Hiernaux, D. (2005). ¿Identidades móviles o movilidad sin identidad? El individuo moderno en transformación [Identities in motion or mobilities without identityThe transformation of the modern individual]. Revista de Geografía Norte Grande, 34, 5-17. Retrieved from http://www.redalyc.org/articulo.oa?id=30003401

Kim, Y., \& Eves, A. (2012). Construction and validation of a scale to measure tourist motivation to consume local food. Tourism Management, 33, 1458-1467. doi:110.1016/j.tourman.2012.01.015

Kim, Y., Yuan, J., Goh, B., \& Antun, J. (2009). Web marketing in food tourism: A content analysis of web sites in West Texas. Journal of Culinary Sciences and Technology, 7, 52-64. doi:10.1080/15428050902788352

Kivela, J., \& Crotts, J. (2006). Tourism and gastronomy: Gastronomy's influence on how tourists experience a destination. Journal of Hospitality \& Tourism Research, 30(3), 354-377. doi:10.1177/1096348006286797

Kooijmans, A., \& Flores-Palacios, F. (2014). Is eating science or common sense? Knowledge about natural food consumers, vendors and producers in rural and urban Mexico. Appetite, 81, 37-43. doi:10.1016/j.appet.2014.06.004

Lin, Y., Pearson, T., \& Cai, L. (2011). Food as a form of destination identity: A tourism destination brand perspective. Tourism and Hospitality Research, 11, 30-48. doi:10.1057/thr.2010.22

Lipovetsky, G., \& Serroy, J. (2015). La estetización del mundo vivir en la época del capitalismo estético. [Aestheticization of the world. Living in the era of aesthetic capitalism]. Barcelona: Anagrama.

MacCannell, D. (1976). The tourist: A new theory of the leisure class. New York, NY: Schocken.

Mak, A., Lumbers, M., Eves, A., \& Chang, R. (2012). Factors influencing tourist food consumption. International Journal of Hospitality Management, 31, 928-936. doi:10.1016/j.ijhm.2011.10.012

Moon, S. (2008). Buddhist temple food in South Korea: Interests and agency in the reinvention of tradition in the age of globalization. Korea Journal, 48, 147-181. Retrieved from https:/www.ekoreajournal.net/issue/view_pop.htm? $\mathrm{Idx}=3480$

Muchnik, J. (2006). Identidad territorial de los alimentos: Alimentar el cuerpo humano y el cuerpo social [Territorial identity of food: Feed the human body and the social body]. In A. Alvarez, F. Boucher, F. Cervantes, A. Espinoza, J. Muchnik, \& D. Requier-Desajardins (Eds.), Agroindustria Rural y Territorio, Tomo I: Los Desafíos de los Sistemas Agroalimentarios Localizados [Agribusiness and Rural Planning, Volume I: The Challenges of Localized Agrifood Systems] (pp. 79-101). México: UAEMEX, IICA, CIRAD.

Nuryanti, W. (1996). Heritage and posmodern tourism. Annals of Tourism Research, 23, 249-260. doi:10.1016/01607383(95)00062-3

Okumus, B., Okumus, F., \& McKercher, B. (2007). Incorporating local and international cuisines in the marketing of tourism destinations: The cases of Hong Kong and Turkey. Tourism Management, 28, 253-261. doi:10.1016/j. tourman.2005.12.020

Omar, S. R., Karim, S. A., Bakar, A. Z. A., \& Omar, S. N. (2015). Safeguarding Malaysian Heritage Food (MHF). The impact of Malaysian food culture and tourists, food culture involvement on intentional loyalty. Procedia - Social and Behavioral Sciences, 172, 611-618. doi:10.1016/j.sbspro.2015.01.410

Ottenbacher, M., \& Harrington, R. (2013). A case study of a culinary tourism campaign in Germany: Implications for strategy making and successful implementation. Journal of Hospitality \& Tourism Research, 37, 3-28. doi:10.1177/ 1096348011413593

Presenza, A., \& Del Chiappa, G. (2013). Entrepreneurial strategies in leveraging food as a tourist resource: A crossregional analysis in Italy. Journal of Heritage Tourism, 8, 182-192. doi:10.1080/1743873X.2013.767810

Quan, S., \& Wang, N. (2004). Towards a structural model of the tourist experience: An illustration from food experiences in tourism. Tourism Management, 25, 297-305. doi:10.1016/S0261-5177(03)00130-4

Ron, A., \& Timothy, D. J. (2013). The land of milk and honey: Biblical foods, heritage and Holy Land tourism. Journal of Heritage Tourism, 8, 234-247. doi:10.1080/1743873X.2013.767817

Rubio, M., Torres, N., Gutiérrez, J., \& Méndez, R. (2004). Composition and sensory evaluation of lamb carcasses used for the traditional Mexican lamb dish, barbacoa. Meat Science, 67, 359-364. doi:10.1016/j.meatsci.2003.10.022

Son, A., \& Xu, H. (2013). Religious food as a tourism attraction: The roles of Buddhist temple food in western tourist experience. Journal of Heritage Tourism, 8, 248-258. doi:10.1080/1743873X.2013.767815 
Stake, R. (2000). Case studies. In N. Denzin, \& Y. Lincoln (Eds.), Handbook of qualitative research (pp. 435-454). London: Sage.

Stanley, J., \& Stanley, L. (2015). Food tourism: A practical marketing guide. Wallingford: CAB International.

Teixeira, V., \& Ribeiro, N. (2013). The lamprey and the partridge: A multi-sited ethnography of food tourism as an agent of preservation and disfigurement in Central Portugal. Journal of Heritage Tourism, 8, 193-212. doi:10. 1080/1743873X.2013.767813

Thomé-Ortiz, H. (2008). Rural tourism and peasantry, a social approach from ecology, culture and economy. Convergencia, 47, 224-249. Retrieved from http://www.researchgate.net/publication/228557659

Thomé-Ortiz, H. (2015). Agri-food tourism and, new social metabolisms of local products. Revista Mexicana de Ciencias Agrícolas, 6, 1373-1386. Retrieved from http://cienciasagricolas.inifap.gob.mx/editorial/index.php/ Agricolas/article/view/4150

Thoms, A. (2009). Rocks of ages: Propagation of hot-rock cookery in Western North America. Journal of Archaeological Science, 36, 573-591. doi:10.1016/j.jas.2008.11.016

Timothy, D. J. (Ed.). (2016a). Heritage cuisines: Traditions, identities and tourism. London: Routledge.

Timothy, D. J. (2016b). Personal heritage, intergenerational food and nostalgia. In D. J. Timothy (Ed.), Heritage cuisines: Traditions, identities and tourism (pp. 65-76). London: Routledge.

Timothy, D. J., \& Boyd, S. (2006). Heritage tourism in the 21 st century: Valued traditions and new perspectives. Journal of Heritage Tourism, 1, 1-16. doi:10.1080/17438730608668462

Timothy, D. J., \& Ron, A. (2013). Understanding heritage cuisines and tourism: Identity, image, authenticity, and change. Journal of Heritage Tourism, 8, 99-104. doi:10.1080/1743873X.2013.767818

Ward, P. (1998). Future livelihoods in Mexico City: A glimpse into the new millennium. Cities, 15, 63-74. doi:10.1016/ S0264-2751(97)10014-2

Warden, A., \& Martens, L. (2000). Eating out: Social differentiation, consumption and pleasure. Cambridge: Cambridge University Press.

Warden, A., \& Tomlinson, M. (1995). Taste among the middle clases, 1968-88. In T. Buttler \& S. Mike (Eds.), Social change and the middle clases (pp. 241-256). London: UCL Press. 